\title{
Financial Development and Poverty Reduction: Exploring the Links between the Issues Using Evidence from Bangladesh
}

\author{
Joynal Abdin ${ }^{1}$ \\ ${ }^{1}$ Business School, University of Hull, UK \\ Correspondence: Joynal Abdin, Business School, University of Hull, UK.
}

Received: May 30, 2016

Accepted: June 15, 2016

Online Published: June 25, 2016

doi:10.5430/ijfr.v7n4p44

URL: http://dx.doi.org/10.5430/ijfr.v7n4p44

\begin{abstract}
This paper estimates the impact of financial development and financial instability on poverty reduction. From a time series data set of Bangladesh in the period between 1974 and 2013, this study finds a significant and theoretically meaningful relationship between the issues. Results suggest that financial development reduces poverty directly by providing greater credit access along with savings opportunity for the poor and indirectly via promoting economic growth. Notwithstanding the positive impacts of financial development on poverty reduction, financial instability which arises alongside financial development is adverse to poverty reduction process. The more interesting finding is that, with comparing to the findings of similar studies, the private credit ration has substantially stronger impact on the income of the poor. And it may be for the presence of ample micro-credit programs in Bangladesh.
\end{abstract}

Keywords: financial development, economic growth, poverty reduction, microcredit, low-income country

\section{Introduction}

\subsection{Background}

The role of financial intermediation on economic growth has been the subject of much concern in development economics over the decades, while little attention has been given on the impact of financial development on poverty reduction. More particularly, a very few empirical studies have looked into whether development in financial sector has any impact on reducing poverty in the low-income countries.

Furthermore, prevailing poverty in the low-income countries is considered the root of all socio-economic problems, and it is suppose that limited access to formal credit and financial services for poor is the cardinal factor behind this poverty.

So, how financial sector effects poverty in the low-income countries is a related issue as it is already supported by the literature that economic growth is an influential instrument for poverty reduction and development in financial sector promotes economic growth (Dollar et al., 2013, Bruno et al., 1998). However, in some cases, instead of reducing poverty economic growth induces income inequality in the society by the volatility that accompanies with growth (Kanbur, 2001). From this above issues interest has been arisen in investigating the explicit effect of financial development and its instability on poverty.

\subsection{Research Focus}

Generally, in theoretical literature, it is argued that financial development can help to reduce income inequality and poverty directly by providing credit and financial services to the poor that helps to increase their income through investing productive activities as well as through interest earned from savings, and indirectly by its growth stimulating effect (Schumpeter, 1934, McKinnon, 1973). On the other hand, Easterly et al. (2001) argued that instability arises in financial sector along with its development and that may prevent poverty reduction process through negative effects of growth volatility and high inflation rate it because poor are more vulnerable to these.

Though Bangladesh has developed in financial sector and experienced a modest reduction in poverty in the last few decades, poverty is still considered the overriding concern of Bangladesh. While in order to alleviate poverty a sound financial system has been long recognized, the impact of development in financial sector on poverty has hardly been empirically investigated in Bangladesh. This paper tries to fill this research gap.

\subsection{Research Objectives and Research Questions}

The aim of this study is to investigate the impacts of financial development and financial instability on poverty through direct and indirect channels in Bangladesh. To explore the issues this paper has two specific questions: 
(1) Does financial development (better access to savings and credit opportunities) work to reduce poverty in Bangladesh, directly or indirectly?

(2) Does financial instability, which accompanies with financial development, weakens the beneficiary impacts of financial development on poverty and thus detrimental to the poor?

To address these questions, first this study tries to measure the impacts of the development in financial system on poverty through direct and indirect channels by using the empirical model adapted from (Jeanneney and Kpodar, 2011).

\subsection{Value of This Study}

This study may have some distinctive features and aims to contribute in several ways to the literature in this field.

First, it is a comprehensive effort to explore the role of financial sector development in alleviating poverty from Bangladesh.

Second, most of the previous studies (as Dollar and Kraay, 2002, Honohan, 2004, Beck et al., 2007a) focused only on the credit facility that provided by the financial institution to the poor, but apart from this, according to Keynes (1937), financial sector also provides savings opportunities to the poor that may affect income of the poor through "conduit effects" (McKinnon, 1973). This model includes not only credit ration but also liquidity ration to know the effect of savings facility on poverty as well.

Third, this study investigates more conclusively the effects of financial instability on poverty in Bangladesh.

Thus, this paper surely will conclude with some policy implications for Bangladesh, as well as for various low-income countries, to reduce poverty through financial development and combat with the instability of financial sector.

\subsection{Outline Structure}

The following of this paper is structured as follows: chapter 2 presents theoretical literatures and empirical evidences on the direct and indirect poverty reduction effects of financial development as well as its instability. This chapter also presents the picture of financial development and income inequality in Bangladesh. Chapter 3 describes the model, data sources with definition of variables and methodology. Chapter 4 is the core of this study, where empirical results of the analysis are presented. Chapter 5 discusses about the result in relation with academic literatures and economic reality, and offers policy recommendations. Finally, chapter 6 draws conclusion of this study.

\section{Review of Related Literature}

\subsection{Theoretical Literature Review}

Poverty reduction through financial sector development has gained great importance in developing countries over the last few decades and theoretical analysis of these issues have gone through various phases in the literatures on development economics. From the existing literatures it is found that financial development can affect poverty through two channels: it works directly through broadening access to finance by the underprivileged, and works indirectly mainly through economic growth.

\subsubsection{Direct Impacts of Financial Development on Poverty Reduction}

From the theoretical grounds, financial sector development can directly contribute to poverty reduction and can help to increase income of the poor in developing country in many ways.

Firstly, developed financial intermediaries can reduce poverty directly by providing improved access to credit market and financial services for the poor. But, developing countries are facing various market failures in financial sector like asymmetric information and the excessive fixed cost associated with small amount of credit borrowing (Stiglitz, 1993). Stiglitz and Weiss (1981) mention that these imperfections create moral hazard and adverse section in under developed financial market and thus prevents poor borrowing from formal financial institutions to invest in profitable activities. This finance deprivation is considered one of the cardinal factors behind persisting poverty (Levine, 2008). Some scholars (Jalilian and Kirkpatrick, 2002, World, 2001) rightly pointed out that a developed and well-functioning financial system can strengthen the productivity of the poor by providing them with the access to financial service, especially to the formal credit, thereby, enhances productive assets of the poor and increases their potentiality for earning sustainable livelihoods.

Secondly, a malfunctioning financial system causes more income inequality in the society by distributing capital disproportionately and by keeping wealth-deficient investors away from the capital flow. Several scholars (Banerjee and Newman, 1993, Aghion and Bolton, 1997, Galor and Zeira, 1993) have asserted that imperfections in financial system creates credit constraints, which affects mainly the poor as they neither hold collateral and credit histories to 
access bank credit, nor they own resources to fund their own project. Development in financial sector can improve the efficiency of capital allocation by reducing information gap that allows poor to obtain external finance and from this point of view financial development can play a vital role in reducing poverty.

Thirdly, Developed financial sector not only provide credit facilities to the poor but also creates savings opportunities for them. Keynes's (1937) theory of demand for money that was rehabilitated by McKinnon (1973) assumed that financial intermediaries are useful to the poor, even if they do not provide credit, because they offering profitable savings opportunity. By doing this financial intermediaries helps to build capital by accumulating scattered savings and enables the poor to borrow money from this accumulated savings to start micro and small-sized enterprises (SMEs) along with interest earning, which eventually reduces poverty by generating more employment and higher incomes (DFID, 2004).

Fourthly, Many scholars (Beck et al., 2007a) are of the view that development in financial sector opens the door of financial market for a large portion of the population of the country and beneficiary impacts of this sector are also enjoyed by the large portion of the people. So, benefits of the financial development are enjoyed by the poor proportionately. However, Greenwood and Jovanovich (1989) argued that there is a nonlinear inverted U-shaped relationship between income inequality and financial sector development - as financial system starts to grow only a few individuals and firms, those who are relatively rich, have access to finance for their high turnover-projects, but later at the higher level of development more people gain access to the system.

On the contrary, some scholars have doubt whether financial development narrows the wealth gaps or widens wealth disparity even if it is helpful to boost aggregate economic growth. Moreover, some are deeply sceptical about broadening of access to financial services for the poor by the financial development, more particularly at the early stage. Haber (2005) states that primarily the reach and the politically connected people would get benefit from developed financial system and development in financial system may flourish only in directing more capital to the selected few.

In addition, Classes and Feijen (2007) mention that financial intermediaries can reduce the risk of falling into poverty and helps to cope with socio-economic shocks as well as reduce the vulnerability to any untoward situation by providing services like insurance, special loan, and savings.

Discussion above implies that there are strong theoretical grounds in supporting direct poverty reduction impacts of financial development.

\subsubsection{Impact of Financial Development on Poverty through Economic Growth}

Besides this direct poverty reduction impact, financial development can impact poverty as well as incomes of poor indirectly through promoting economic growth and contributes to reduce poverty (Caprio and Honohan, 2001).

In the literature, role of financial development in economic growth is a debatable issue. In the earlier development economic theory, it is thought that finance had no significant role in promoting growth and the matters for economic growth were technological advancement and growth in labour supply only (Solow, 1956). But after the emergence of endogenous growth theory this thought has been changed. Endogenous growth theory confesses the positive impact of financial intermediaries on economic growth and according to this theory by positively impacting capital mobilization and savings accumulation financial intermediation has a promoting role in technological innovation and economic growth (Romer, 1986, Aghion and Howitt, 1990).

Some, those who do not believe in the positive role of the finance and monetary systems on economic growth, argue that financial intermediation does not promote growth rather economic growth leads monetary system towards development. For instance, Robinson (1954: p.86) clearly pointed out that "where enterprise leads, finance follows", - it means financial development always follows by economic growth, it because general tendency is that the supply of finance moves with the demand for it.

Robert Lucas (1998) also dismisses the impact of finance on economic growth and he expressed that the alleged positive role of finance on growth is over-stressed in the literature.

Moreover, some (Van Wijnbergen, 1982, Buffie, 1984) claimed that financial development can have none and in some cases negative impact on economic growth. It because, along with the financial development funds moves to formal capital market from the controlled banking system and for the presence of reserve requirement in the formal capital markets all of the available funds cannot advance at a time. For this reason domestic credit supply could be reduced that can detain economic growth by reducing investment and lowering production.

Actually, the above theories were based on the assumption of the classical market clearing theory that "supply creates its own demand", which means that the surplus of savers is transferred to borrowers who need the funds. 
However, in reality this is not true; markets do not always clear. In reality, for efficient allocation of capital from savers to investors and sharing risks financial sector plays a vital role and its development is a must.

On the other hand, those who do believe in the existence of a positive role of developed financial sector for promoting economic growth argue that a developed and well-structured financial system plays a critical role in an economy by affecting domestic saving, capital building, technological improvement, and economic growth, or vice versa. It also ensures reallocation of resources to the most productive projects. This view is supported by the huge body of recent empirical evidences (King and Levine, 2004).

Some of the greatest economists, Goldsmith (1969) Schumpeter (1934) and McKinnon (1973), have given importance on finance for economic growth. Almost a century ago, the pioneering study of Schumpeter (1934) identified the positive impact of developed financial system on total productivity and economic growth. The financial intermediations through the banking system play a pivotal role in the enhancement of technological changes as well as economic development by providing required services like channelling the capital to high-yielding investment, thus technological innovation, productivity improvement, and high growth (ibid.).

Later, two main Schools of thoughts regarding the debate over how financial development encourages economic growth: the Financial Repressionist School and the Financial Structuralists School, have advocated a highly developed and liberalized financial system for economic growth.

The well-known analysis of the pioneer of the Financial Repressionist School Shaw (1973) and McKinnon (1973) emphasized on the free interest rate and they give importance of the elimination of distortion in the prices of financial services for liberalization of the financial system and this liberalization induces savings, investment and economic growth.

Moreover, growth enhancement by financial intimidations argument is also supported by the new economic growth theories of Romer (1986) and, Jappelli and Pagano (1994).

The Financial Structuralists School exerts that the expansion of well-developed financial institutions and their activities tends to increase savings, thus stimulate economic growth by directing this savings to profitable investments (Shaw, 1973, Goldsmith, 1969, Patrick, 1966).

From the above theoretical grounds it is clear that financial development has remarkable role to promote economic growth, as Merton Miller (1998) said that "the financial markets contribute to economic growth is a proposition too obvious for serious discussion."

Now, to examine whether this growth transmitted into poverty reduction we are going to discuss the existing literatures in this field.

The very prominent trickle-down theory has implied that there is a positive association between economic growth and poverty reduction. Aghion and Bolton (1997) state that the benefits of developed financial sector may trickle down to the poor via the redistribution of wealth from rich to poor. This trickle-down theory is extensively supported by various empirical investigations (such as Datt and Ravallion, 1992, Dollar et al., 2013).

Though, well-known classical inverted-U hypothesis of Simon Kuznets (1955) states that, more or less inevitable, economic growth causes income inequality as poor economy start to grow then it fall at the mature stage of development, later it was not supported by the expanded studies of Milanović (2010) and Ravallion (2007).

However, Dollar and Kraay (2002) stated that economic growth is essential for improving the lives of the poor but it is not in the every cases that growth surely brings benefit for poor.

Generally, a lot of variation is observed in overall one-to-one relationship between inclusive economic growth and average increase in the income of poorest household. The fact behind this variation is that, countries of similar GDP level are showing great difference in human development activities, as stated in the annual Human Development report of UNDP (UNDP, 2013).

Moreover, some studies (Lipton and Ravallion, 1993, Somavia, 2003, Lustig et al., 2002) correctly pointed out that the effectiveness of growth in depleting poverty mostly depends on the nature of growth and pattern of income distribution.

From the above literatures it is clear that, though economic growth is not all that matters for combating poverty, it's a major tool for reducing poverty.

2.1.3 Others Indirect Impacts of Financial Development on Poverty Reduction

Financial sector could affect incomes of households as well as poverty in many ways without direct use of financial intermediations by the poor (Beck et al., 2007b, Townsend and Ueda, 2006). Such as, developed financial system could intensify economic activity which boosts the demand for labours. For this increasing labour demand, demand 
for un-skilled labour also increases; this increasing labour demand for the indirect impact of financial development could reduce poverty.

\subsubsection{Role of Microfinance in Developing Countries}

From the existing literature, it is found that to boost growth and combat with poverty through financial development developing countries should emphasise on small local banks and micro-finance, because in the large banking system credit is costly and even unavailable for the poor.

Justin Lin (2009) suggested that developing nations should consider local small banks as the linchpin of its financial systems. He support this by saying that the prime objectives of financial sector is to fulfil the demand of the most prominent sectors of the economy, and in developing countries this prominent sector is influenced by the micro-enterprise, SMEs, service firms, and farming. To ensure the best financial service to these sectors small and local banks are the best choice for developing countries.

Thoma (2009) added that, to meet basic financial needs developing countries need small banks and microfinance along with this they also need more advanced financial services and products like insurance to mitigate the risks.

But, some have argued that lack of access to financial service is not the only constraint to the SMEs. Recent study of Asian Development Bank (2009) on micro-enterprises found that there are many constraints to the advancement of these organizations, and lack of access to formal credit and other financial services is only one of the major limitations along with others like limited access to new technologies and to market dynamics.

\subsection{Empirical Evidence}

This section will review and survey the empirical literature on the role of financial development in poverty reduction.

\subsubsection{Cross-country Studies}

Empirical evidences on cross-country studies of the impact of financial development on poverty are well established and widely accepted in spite of variation in methodology among these studies.

Several researchers, including Jalilian and Kirkpatrick (2002), Honohan (2004), Beck et al. (2004), Perez-Moreno (2011) and Clarke et al. (2013) employed investigation, using multivariate regression, to know how an explanatory variable like private credit ratio to GDP is explained by the dependent variable like poverty gap, while controlling other variables like inflation rate, political stability, quality of governance that may also affect the dependent variable, found that financial development has direct poverty reduction impacts.

Clarke et al. (2013) examined a panel data set from 91 countries, covering period 1960 to 95, and provided with the result that income inequality reduces as financial intermediation starts to develop, consistent with the result of the previous work (as found by Banerjee and Newman, 1993, Galor and Zeira, 1993). However, these studies did not show any evidence of so-called inverted-U relationship of financial development and income inequality, which contrasts with previous work of Greenwood and Jovanovic (1989).

A very famous study of Beck et al. (2007a) assessed the effect of development in the financial system on income of the poor and overall income distribution. Their study found that financial development helps to increase the incomes of the poorest quintiles. Study showed that the growth in the income of the poor is faster than the average growth in GDP per capita. The interesting findings of their study is that $60 \%$ of the improvement in the income of the poor is for aggregate economic growth that causes by financial development and the rest $40 \%$ is for the direct impact of the financial development on the income of the poor.

\subsubsection{Country-specific Studies}

Along with these cross-country studies of above, country-specific investigation tried also to explore whether financial development has any impact on poverty alleviation as well as on aggregate economic growth.

Odhiambo (2009) examines the dynamic causality between financial development and poverty alleviation in South Africa with a trivariate causality model. Results indicate that poverty is reducing in South Africa by the Granger-cause of both the financial development and economic growth. Another interesting finding of this study is that, not only financial development causes economic growth but also economic growth causes financial development which leads to poverty alleviation. Using similar approach, working with data from Kenya during the period 1969 to 2006, Odhiambo (2010) also showed that development in financial intermediaries helps to increase domestic savings and this savings cause poverty reduction.

Husain (2004) found that the reform in financial sector of Pakistan has resulted in favourable and beneficial to the poor and they have easy access to the formal credit after these reformative initiatives. 
Burgess et al. (2005) showed that for the increasing opportunity of saving accumulation and loan provision in rural area of India, poverty is reducing there considerably.

On the contrary, Fowowe and Abidoye (2012) run an investigation to find out the effect of developed financial sector on poverty reduction in Sub-Saharan African countries. They investigate the impact of private credit ratio, as the measure of financial development, on the growth in poverty rate. Results show that there is no significant influence of financial development on poverty eradication.

By and large, theoretical grounds of positive impacts of financial development on poverty reduction are supported by these empirical evidences discussed above.

\subsubsection{Impact Evaluation Studies of Microfinance Programmes}

The findings of the studies on poverty reduction impact of the micro-finance programmes, however, are varied.

Mosley and Hulme (1998) accomplished a special survey about 87 villages of Bangladesh from 1991 to 1992 to know the impact of micro-credit on the poor. They used - increase in consumption of the households, assets building, labour supply and schooling for the children as the measures of improvement, and found that micro-credit positively impacted the consumption level of poor and about $5 \%$ could be to overcome poverty.

Moreover, Khandker (2005) in the another study found positive effect of micro-credit in Bangladesh and results of his study showed that on household expenditure on non-food and non-land assets building positively impacted by credit.

Cotler and Woodruff (2008) found almost the similar impact of small-scale loan in Mexico.

Montgomery (2006) found in Pakistan that socio-economic indicators relating to poor and income generating activity have been increased, especially for relatively poor, as a result of reformative activities for developing micro-finance sector.

Some scholars (Mosley and Hulme, 1998, Coleman, 2006) have found that the effects of micro-credit on poverty reduction are regressive, i.e., micro-credit has almost no effect or negative effect on the hard-core poor but it revolves to increase and positive to the relatively well of households.

However, Roodman and Morduch (2009) by reinvestigated the several previous studies, on the impact of micro finance programme (such as Pitt and Khandker, 1998, Morduch, 2000, Khandker, 2005), have arisen question about the credibility of this studies due to weakness of the methodology of these studies.

Difference in the findings of the impect of micro finance on the income of the poor has pointed out that more rigorous investigations are needed in this field.

\subsubsection{Studies Related to Effect of Financial Development through Growth Channel}

To confirm that the financial sector development can reduce poverty indirect channel through economic growth, first it is necessary to prove empirically that economic growth reduces poverty.

A substantial amount of studies (Datt and Ravallion, 1992, Demery and Squire, 1996, Ravi Kanbur, 1987, Chen et al., 1994, Dollar and Kraay, 2002, Dollar et al., 2013) have been conducted in this field to investigate the necessity of economic growth for reducing poverty and, by and large, concluded with the findings of positive poverty reduction impact of growth. Most of the studies have found that economic growth has positive impact on poverty reduction and growth is necessary for poverty reduction.

It is supported by the empirical studies presented so far that economic growth has positive impact on poverty reduction. Now, we are going to present some evidences as the supporting of the theoretical argument that development in financial sector promotes growth, which consequently reduces poverty.

Based on the ground-breaking work of Goldsmith (1969) and using a data set of 80 countries between 1960 and 1989 (King and Levine, 1993) showed that financial development level (measured by several indicators) has significant, strong and positive association with growth and development. Studies found that about $1 \%$ point increases in the per capita GDP of the country is associated with the increases in the financial depth (measured by the liquidity ratio to GDP).

Though some previous studies (King and Levine, 1993, King and Levine, 2004) are the pioneer among the empirical studies that underline growth promoting impact of finance, the loopholes of their study is that they did not consider probable reverse causality.

Later many researchers have made attempts to take the issue of reverse causality into account. For instance, Levine et al. (2000) using data from 71 countries from 1960 to 1995, employed a study using additional control variables to control reverse causality. Still, the study has found a significantly strong positive impact of financial development on 
growth. Findings suggested, for an instance, that if India could reached on the level of average development level of financial sector of the developing countries over 1960 to 1995 then the yearly real GDP per capita of India would be $0.6 \%$ higher during these period. Findings of above studies is supported by the following studies of Calderón and Liu (2003), Jalilian and Kirkpatrick (2005).

Enormous empirical evidences suggest that developed financial sector has significant and positive impact on economic growth, however, very few studies do not show strong and significant relationship e.g. (Favarra, 2003). However, according to Levine (2005) and (Honohan, 2004), due the weakness of the indicators that used for measuring financial development, more comprehensive study is needed in this field.

\subsection{Financial Development and Income Inequality in Bangladesh}

Like many underdeveloped and developing countries, poverty is a curse for Bangladesh. According to World Bank (Group, 2012), in Bangladesh about 65 million people were living below the poverty line, as defined $\$ 1.25$ per day (PPP), in 2010. However, the actual scenario of poverty has been increased over the last few years and Bangladesh has gained a moderate cutting in poverty, according to IMF this reduction rate is around $1.5 \%$ per annum.

Many international bodies including World Bank, International Monetary Fund and Asian Development Bank suggested that for attracting foreign resources to combat with poverty Bangladesh needs to develop a sound and efficient financial sector. Taking into account these guidelines Bangladesh has started reformative activities in the financial sector from early 1980s. These reforms were divided into two phases.

The first phase of the reforms was started in early 1980s with the denationalization of the banks and by allowing new private banks. The aim of the first phase reforms were: liberalization of interest rate; introduction of new policies for loan classification; abolishing lending to some specific large enterprises; regulating banks; strengthening monitoring of central bank; transformation in banking sector; updating accounting system; developing capital market; computerization of public banks; and improving overall management by amending the legal structure of the financial sector (Uddin et al., 2014, Adnan Hye and Islam, 2013).

In the second phase some other measures were taken including introduction of floating foreign exchange rate, measures for improving the capital base of commercial bank, reforms in legal framework to induce debt recovery, and introducing indirect monetary instrument instead of direct credit control (Rahman, 2004).

The positive results from financial sector reformers in Bangladesh has reflected in the real gross GDP, which increases at an average rate of 5.8 percentage point per annum over the period 2000 to 2009 as compared with 5.5 percentage point over the period 1995 to 1999 . Though this increase in GDP growth is not only for the financial development, this improvement indicates that reform in the financial sector with a view to develop financial system is crucial for Bangladesh.

Another important characteristic of the financial sector of Bangladesh is the presence of a substantial numbers of MFIs with their micro-credit activities. These microfinance organizations provide loans to the poor without any collateral.

\subsection{Conclusion}

Existing theories predict that development in financial sector can reduce poverty directly by influencing income of the poor and indirectly via economic growth. In addition, empirical studies provide strong evidence that this relationship is statistically significant and economically meaningful. Despite the growing use of the concept of financial development, there are little empirical evidence on poverty reduction impacts of financial development and financial instability from low-income countries like Bangladesh.

\section{Methodology}

\subsection{Model Specification}

To carry out this analysis I employ a standard poverty model that is adapted from the previous studies (Jeanneney and Kpodar, 2011, Dollar and Kraay, 2002, Honohan, 2004, Kpodar and Singh, 2011).

First, we have two assumptions about the effects of financial sector development on poverty and income inequality:

1. By providing easy access to the formal credit by the poor financial intermediary development has a direct positive impact on the poverty reduction.

2. Financial development promotes economic growth and economic growth helps to reduce poverty. However, insatiability in financial sector hinders this process and reduces the benefits of financial development. 
Based on these two assumptions specified model aims to examine the impact of financial development on poverty reduction through direct channels and via its influence on economic growth. The model also aims to explore the impact of financial instability with adding financial instability variables in the specified model.

The baseline model suggests that incomes of the poor are explained by the real per capita GDP, financial development level as well as instability of financial sector. The model also explains poverty by adding some additional variables including inflation, GDP growth rate, trade openness and number of bank branches as control variables in the basic specification (following Dollar and Kraay, 2002, Easterly and Fischer, 2001).

The baseline model is as follows:

$$
P v_{t}=\alpha_{0}+\alpha_{1} y_{t}+\alpha_{2} F d_{T}+\alpha_{3} F i_{T}+\alpha_{4} \operatorname{Infl} l_{T}+\varepsilon_{t}
$$

where, $P v$ is the poverty indicator, $y$ represents the real per capita GDP; $F d$ refers financial development level; and $F i$ indicates instability in financial sector; Infl denotes the rate of inflation rate, which is added as an additional control variable; $t$ is poverty and income measurement year; $\mathrm{T}$ indicates the period of other variables measurement; $\varepsilon_{t}$ is the error term; and $\alpha$ is the parameter.

In this study I also consider several additional specifications. The first additional specification examines whether the beneficial impact of financial development depends on the access to the banking system by the poor and for measuring this the number of bank branches per $\mathrm{km}^{2}$ is used.

The second additional specification tests whether the growth instability and inflation volatility is detrimental to the economic development and poverty reduction process.

Finally, to test robustness the model introduces some microeconomic variables: primary education, government consumption and trade openness which are some important determinants of poverty (Christiaensen et al., 2003).

\subsection{Data Sources and Definition of Variables}

The study is conducted using annual time series data of Bangladesh in the year from 1974 to 2013. The data are collected from different sources, including World Bank, International Monetary Fund, Bangladesh bank and Bangladesh Bureau of Statistics. The sub-section below defines the variables and also mentions the sources of the data.

\subsubsection{Poverty}

First, to measure the level of poverty average per capita income (in 2005 constant dollars) of the poorest 20 percent of the population of Bangladesh is used. Like many other developing countries data on poverty in Bangladesh are inadequate. World Bank database and Dollar and Kraay database are comparatively rich and from this database I select 17 observations between 1774 and 2011. I create other observations using World Bank povcalNet software.

As a second poverty indicator, I use the headcount index, which indicates the percentage of population living below the national poverty line. In Bangladesh national poverty line is measured by using the Cost of Basic Needs (CBN) methods and defined as calorie intake of 2225 kilocalorie per person a day. In this case data is also scant and I have only 33 observations out of 40, for the period of the year 1974 to 2013 from the database of Bangladesh Bureau of Statistics and world development indicator database of World Bank.

Using povStats and povcalNet database of World Bank I use poverty gap as the third poverty indicator in this study. Poverty gap indicates the distance of the poor from the poverty line defined by the World Bank as $\$ 1.25$ income a day (PPP \%).

\subsubsection{GDP per Capita}

For measuring the indirect effect of financial development on poverty reduction through economic growth, GDP per capita income is used as explanatory variable in the model. I use the data on GDP per capita of Bangladesh in constant 2005 US \$ at PPP from World Development Indicator database of World Bank.

\subsubsection{Variables of Interest}

Financial development and financial instability are used as the variables of interest in this study.

Financial development:

For measuring financial development two indicators are used in this model. These are as follows:

1. The ratio of liquid assets of the financial sector to GDP (M3/GDP); and

2. The ratio of private credit giving by financial intermediaries to GDP. 
To measure poverty reduction impact of financial sector development some previous studies (e.g. Beck et al., 2007a, Honohan, 2004) have used only credit ratio, but I consider both credit and liquidity ratio for assessing more accurately whether financial sector development are actually helpful to reduce poverty.

I obtain data from World Development Indicator and Global Financial database of World Bank. For this two variables average data of five years (from the poverty measurement year to previous four years) are used.

Financial instability:

Financial instability indicates the deviation of the financial development indicator from the trend. To estimate instability standard deviation, the most common measures of volatility, is used. I estimate the standard deviation of the growth rate of the related variable to measure its instability, defined as follows:

$$
V^{x}=\sqrt{\sum_{t=1}^{n} \frac{1}{n-1}\left(g_{t}^{x}-\overline{\mathrm{g}}^{x}\right)^{2}}
$$

where, $V^{x}$ denotes the instability of the variable $\mathrm{x}$, and $g^{x}$ is the growth rate of $\mathrm{x}$.

\subsubsection{Control Variables}

In the baseline model inflation rate (consumer price index) is included as a control variable to control for the macroeconomic environment. I also include number of bank branches per square kilometer to measure the ability of access to financial services, government expenditure to measure the impacts of social safety net measures for the poor, primary school enrollment to assess the human development, and trade openness index to assess the degree of free market economy. I obtain data for these variables using world development indicator database of World Bank.

\subsection{Econometric Techniques and Methodological Issues}

First, OLS regression is run to estimate the model using Stata 13. Then, Generalized Method-of-Moment (GMM) estimator is used to address the presence of endogeneity, omitted variables bias and measurement error problem, again using Stata 13.

OLS estimator may cause bias and inconsistent results due to presence of overlapping in the set of unobservable variables called unobserved heterogeneity. But GMM estimator has several advantages (Bond et al., 2001) and it is used to correct for bias caused by endogenous explanatory variables. To avoid the heteroscedasticity in the regression analysis Robust command is used at the time of running Stata 13.

The following tests were carried out:

- T-test is carried out to test whether the coefficient is statistically significant and for testing the goodness of fit of the coefficients.

- Shapiro-Wilk test is also run to test the normality of the data that used for this study.

- To identify whether multicollinearity is presence, Variance Inflation Factor (VIF) indicator tests are run.

- Finally, Durbin-Watson test is run for testing whether autocorrelation is present among the variables.

\subsection{Limitations}

The two major limitations of my study are insufficient data coverage for some specific variables and relatively short length of the study. Like some other developing economy, time series data on poverty are limited in Bangladesh.

\section{Results}

\subsection{Representation and Interpretation of Empirical Results}

The results, in general, show that financial development has a significant and positive poverty reduction effects and its direct impact on poverty alleviation is stronger than the indirect impacts through economic growth channel.

Impacts on income of the poorest quintile:

The results related to effects on the income share of the poor by the two indicators of the financial development, liquidity ratio (M3/GDP) and privet sector credit ration (credit/GDP), are presented in the table 1 and 2 (in Appendix B). In both table, column 1, 2 and 3 show the OLS estimators and rest of the column show the GMM estimators.

Table 1 presents the estimated regression coefficients of the effect of the first indicator of financial development (the liquidity ratio, M3/GDP) and its instability on dependent variable (log of income of the poorest 20 percent). Results show that variable of interest M3/GDP is positively and statistically significantly (at $1 \%$ level of significance) related to the income of the poor. On the other hand, another variable of interest, the instability of M3/GDP, is inversely but statistically significantly (at 10\% level of significance) associated with the income of the poor. 
So, in both of the cases the, hypothesis of the relationship between the variables cannot be rejected and these relationships are not only statistically significant but also economically meaningful. From the results it is evident that financial development could increase income of the poor in Bangladesh, on the other hand financial instability causes reduction in it. These findings are supported by the present literature in this field.

By comparing column 2 to 3 and 4 to 5 , it is clearly found that after adding instability of M3/GDP as an additional variable the coefficient of the M3/GDP reduces in magnitude. This suggests that stable financial system is more beneficial to the poor then unstable one.

The estimated coefficient of the impact of per capita GDP on income of the poor, in column 3, shows that per capita GDP has positive and significant impact on the income of the poor. The coefficients in column 6 and 7 further confirm that economic growth fosters the income of the poor and at the same time instability in economic growth negatively impacts it.

In column 8 , the coefficient of proxy variable of access to banking system (creating by interacting between the number of bank branches per square kilometer and M3/GDP) has a positive coefficient, though it is not statistically significant. It suggests that availability of bank branch has positive impacts on the income of the poor.

The interesting result is shown in the coefficient of another proxy variable creating with the interaction between liquidity ratio and GDP per capita. It has a negative significant coefficient (in column 90 f Table 1), which suggest that the liquidity ratio has more powerful poverty reduction impact at low income level. These results confirm the relevancy of "McKinnon conduit effect" to the low income countries.

Table 2 presents the results of the impacts of the other variable of interest, private credit ratio (credit/GDP) and instability of credit/GDP on the incomes of the poor. These results also suggest that there is a strong and statistically significant relationship between the variables.

According to the coefficients of column 3 and 7, GDP per capita and its growth have positive impact on income of the poor, and instability in growth has impacted it negatively.

The coefficient of the interaction of the M3/GDP and number of the bank brunches (in column8) has negligible but statistically significant impact on the income of the poor. Another proxy variable, creating with interaction between credit ratio and per capita income, is positively related with the income of the poorest quintile.

Table 1 and 2 show that, in all the cases regression coefficients of the inflation rate has negative sign, which indicates that inflation reduce the income share of the poor. Though it is statistically not significant at conventional level, economically it is right.

Impact on headcount poverty rate:

The base model is also estimated with the second measures of poverty, the percentage of the population living below the national poverty line measured by the cost of basic needs (CNB) at 2225 kilocalories food intake in a day. The estimated results of the coefficients using by stata are presented in table 3 and 4 in Appendix B. The sign of the most of the coefficient are as expected and most of the estimated coefficients are statistically significant at the conventional level.

Column 3 and 5 of these table show that both of the indicators of the financial development, the liquidity ratio and credit ratio, are negatively associated with the incidence of poverty. That means financial development reduces headcount poverty and results also show that instability of the both variable increase the headcount poverty.

Table 3 shows that almost all of the estimated coefficients of the variables of interest are statistically insignificant. According to the results, GDP per capita and GDP growth help to reduce poverty, but both inflation volatility and growth instability are detrimental to the poor.

Impact on poverty gap:

The model is estimated again with poverty gap, the third indicator of poverty, defined as the percentage of the population living below the poverty line of income $\$ 1.25$ a day. The estimated results relatied to this variable are shown in the table 5 and 6 . The results corroborate the pervious findings significantly and show that financial development could reduce the poverty gap.

Impact on economic growth:

Table 7 (in Appendix B) shows that financial development fosters economic growth in Bangladesh. According to the estimated coefficients, 10 percentage point increases in the M3/GDP has resulted in 1.17 percentage point increases in GDP growth. And, instability in M3/GDP is negatively reflected in GDP growth. Both of the coefficients related to these variables are statistically significant respectively at $5 \%$ and $10 \%$ significance level. 
Result of other test related to fitness of the model:

From the econometric point of view, the fitness of this model and fairness of the estimated result are justified.

To test whether the data that is used in this model are normal, the Shapiro-Wilk normality test was run and results of this test (in Appendix A) show that all of the variable are normally distributed.

For identifying whether there are presence multicollinearity among the variables in the model, Variance Inflation Factor (VIF) indicator tests are run and it is found that VIF indicators do not exceed 4 for any of the variables. So according to experts (Gujarati, 2012) we can say there is no multicollinearity present in this model. Durbin-Watson test is run for testing whether autocorrelation is presence among the variables and results (in Appendix B) show that autocorrelation do not exist among the variables.

\subsection{The Big Picture}

In the table below summary of regression coefficients of the relationship between poverty, financial development, instability of the financial development indicators and economic growth are presented.

Table 8. Summary of the estimated coefficients of the vital variables of the model

\begin{tabular}{llcc}
\hline Explanatory variable & Dependent variable & Value of coefficient & Source of coefficient \\
\hline $\begin{array}{l}\text { Impact of: } \\
\text { Financial development } \\
\text { (M3/GDP) }\end{array}$ & On: & 0.117 & Table 7, column 2 \\
& Economic growth & $(2.70)^{* *}$ & \\
& Poverty reduction: & 0.661 & Table 1, column 5 \\
& Income of the poor & $(3.94)^{* * *}$ & \\
& Headcount poverty & -0.172 & Table 3, column 5 \\
& & $(2.01)^{* *}$ & \\
& Poverty gap & -0.0128 & Table 5, column 5 \\
& & $(0.20)$ & \\
Financial instability \\
(instability inM3/GDP) & Economic growth & -0.856 & Table 7, column 2 \\
& Poverty reduction: & $(1.79)^{*}$ & \\
& Income of the poor & -0.205 & Table 1, column 5 \\
& & $(1.97)^{* *}$ & \\
& Headcount poverty & 9.744 & Table 3, column 5 \\
& & $(3.30)^{* * *}$ & \\
& Poverty gap & 0.091 & Table 5, column 5
\end{tabular}

Economic growth (GDP per capita growth)

\section{Poverty reduction:}

Income of the poor

0.065 $(9.92)^{* * *}$

Headcount poverty

Poverty gap
$-0.068$ $(5.52)^{* * *}$

Table 1, column 5

Table 3, column 5

Table 5, column 5 
In accordance with the summery coefficient, poverty reduction impact of financial intermediary development on poverty and income inequality reduction in Bangladesh is not only considerable but also significant and meaningful.

1. Financial development helps directly to reduce poverty and promote economic growth also. $10 \%$ increase of the financial development (measured by M3/GDP) would directly produce $6.61 \%$ increase in the average income of the bottom quintile of the population. However, the same percentage change of the financial development could reduce headcount poverty and poverty gape $1.71 \%$ and $0.12 \%$ respectively. This percentage of financial development also causes $1.17 \%$ increase in economic growth.

2. Financial development also causes financial instability, which hinders the economic growth and also hampers the poverty reduction process. Table shows that $10 \%$ instability in financial sector translates into $8.56 \%$ drop in economic growth. This amount of instability reduces the income of the poor about $2 \%$. For the same increase of instability both poverty incidence and poverty gap also increase by $0.9 \%$.

3. Financial development also helps to reduce poverty and income inequality through growth channel. A $10 \%$ increase in growth causes $0.6 \%$ improvement in the income of the poorest people and also reduce headcount poverty rate and poverty gap by 0.6 and $0.2 \%$ respectively.

\section{Discussion and Recommendation}

The results from the model suggest that financial development has a positive and significant poverty reduction impact in Bangladesh both directly and indirectly through economic growth. Results also suggest that financial instability go along with financial development and it has the negative impact on poverty reduction.

From the results two most important questions have emerged: are the results justified by the present literature or economic theory? And, do the results actually relevant to the economic reality of the developing countries? I try to address these below.

Most of the present literatures, those have been discussed in the literature review part of this paper, state that financial development has direct and indirect (via economic growth) poverty reduction impact. Literatures also state that through thses impacts financial intermediation helps to improve the income of the poor, thus reduce poverty. So, results of this study confirm the economic theory.

There are theoretical as well as empirical grounds which suggest that as financial sector starts to grow in developing countries, the country is likely to experiences instability in financial sector at the early stage of development for the absence of strong legal and monitoring system (Guillaumont Jeanneney and Kpodar, 2007).

Another view is that, for unstable macroeconomic environment on the way to financial development developing country experiences multiple equilibrium states, switch to crisis equilibrium from non-crises equilibrium. For this reason they face the problem of instability at the beginning of the financial development (Loayza and Ranciere, 2006). The results of the study agree with above theoretical arguments of the present literature.

The interesting finding of this study is the results related to privet credit ratio, which has significant and strong positive impact on the poverty level. This suggests that in Bangladesh poor has easy access to the credit. This results seems to be contradictory with the findings of the Jeanneney and Kpodar (2011). They found that in developing countries the relationship between private credit ratio and poverty reduction is not significant as the access to formal credit by the poor remains challenging in developing countries.

The justification of my findings could be lie in the presence of ample micro-credit programmes in Bangladesh. Generally in developing countries poor do not have easy access to the formal credit for lack of collateral. But in Bangladesh many organizations who work with micro-finance, especially Grameen Bank, provide easy access to credit without any collateral.

Another important finding of this study is that, the number of bank branches would reduce poverty through promoting financial service to the poor. This results confirms the McKinnon conduit effect theory (McKinnon, 1973).

\subsection{Policy Implications and Recommendations}

Some straightforward policy implications have been emerged from the findings of this study. The enormity of poverty reduction impact of financial development emphasises on the importance of financial sector reforms in developing countries.

But, at the same time they must take into account the detrimental impact of financial instability into their policy package. It because the financial instability may hampers or even neutralizes the benefit that can be gained from the 
positive impacts of financial sector development. Economic theory suggests that excessive money supply and lavish government expenditure bring about inflation and this inflation is the one of the main causes of financial instability. External financial openness and excessive trade openness are also vulnerable for low income countries, which brings external shocks to the financial sector. Along with the fragile legal system, lack of standard accounting and absence of strong monitoring all encounter financial stability.

To cope with these external and internal shocks during liberalization of financial sector policy package must tag along sound macroeconomic policies, gradual financial and trade openness, strong legal and monitoring system.

Savings accumulation and mobilization is very important for poverty alleviation, but in developing countries formal bank branches are concentrated in some specific areas and at the early stage of development they are reluctant to do banking at micro level. Therefor, micro-credit program is very useful in developing country. Jeanneney and Kpodar (2011) and Honohan and Beck (2007) rightly suggest MFIs for developing countries.

\section{Conclusion}

The aim of this paper is to explore the impacts of financial development and financial volatility on poverty reduction in Bangladesh. The study is conducted by using liquidity ratio (M3/GDP) and private credit ratio (credit/GDP) as the two indicators of financial development and standard deviation of these two indicators as the measures of financial instability. Applying regression analysis model adapted from previous study (Jeanneney and Kpodar, 2011) and using time-series data from Bangladesh in the year of 1974 to 2013 this paper has concluded with the following results:

(1) Financial development, in general, helps to reduce poverty with the direct positive effect on the income of the poor as well as indirectly through economic growth, and direct effect is stronger than indirect effect.

(2) Financial instability is adverse to the poverty reduction by nullifying the beneficial impact of financial development.

(3) The interesting result is that, compare to the findings of similar studies relating to developing countries the impact of private credit ration on poverty reduction in Bangladesh is considerably high, and it's may be for the presence of adequate micro-credit activities in Bangladesh.

These findings are supported, more or less, by the prevailing literate in this field as well as by the economic theory.

This study comes up with some specific policy implications also. For its substantial poverty reduction impacts it is crucial to reform financial sector in low income countries for alleviating poverty. At the same time developing countries must take preventive measures into their policy package to combat with the detrimental impacts of instability in financial sector that comes along with development of the financial sector. Policy package must tag along sound macroeconomic policies to control excessive inflation as well as strong legal framework and monitoring system to cope with the instability. Gradual liberalization of financial system and restrained trade openness are also required to reduce external and internal shocks during liberalization of financial sector in developing countries.

Taking into account the experience of Bangladesh for providing financial service to the poor, especially providing credit facility, developing country should promote micro finance institutions (MFIs).

Finally, the results of this study should be interpreted as a single entity rather than as a whole of the low-income countries due to different capabilities of financial sectors among these countries. A possible useful extension of this study could be to include most of the low income countries and check whether the basic results of this study hold for all the low-income countries regardless of the structural difference of the financial sector.

\section{References}

Adnan Hye, Q. M., \& Islam, F. (2013). Does financial development hamper economic growth: empirical evidence from Bangladesh. Journal of Business Economics and Management, 14, 558-582.

Aghion, P., \& Bolton, P. (1997). A theory of trickle-down growth and development. The Review of Economic Studies, $64,151-172$.

Aghion, P., \& Howitt, P. (1990). A model of growth through creative destruction. National Bureau of Economic Research.

Asian Development Bank, A. (2009). Key Indicators for Asia and the Pacific 2009.

Banerjee, A. V., \& Newman, A. F. (1993). Occupational choice and the process of development. Journal of political economy, 274-298. 
Beck, T., Demirguc-Kunt, A., \& Levine, R. (2004). Finance, inequality, and poverty: cross-country evidence. National Bureau of Economic Research.

Beck, T., Demirgüç-Kunt, A., \& Levine, R. (2007a). Finance, inequality and the poor. Journal of economic growth, 12, 27-49.

Beck, T., Levine, R., \& Levkov, A. (2007b). Big bad banks? The impact of US branch deregulation on income distribution. National Bureau of Economic Research.

Bond, S. R., Hoeffler, A., \& Temple, J. (2001). GMM Estimation of Empirical Growth Models.

Bruno, M., Ravallion, M., \& Squire, L. (1998). Equity and growth in developing countries: old and new perspectives on the policy issues. Income distribution and high-quality growth, 117-146.

Buffie, E. F. (1984). Financial repression, the new structuralists, and stabilization policy in semi-industrialized economies. Journal of Development Economics, 14, 305-322.

Burgess, R., Pande, R., \& Wong, G. (2005). Banking for the poor: Evidence from India. Journal of the European Economic Association, 3, 268-278.

Calderón, C., \& Liu, L. (2003). The direction of causality between financial development and economic growth. Journal of Development Economics, 72, 321-334.

Caprio, G., \& Honohan, P. (2001). Finance for growth: policy choices in a volatile world. World Bank Publications.

Chen, S., Datt, G., \& Ravallion, M. (1994). Is poverty increasing in the developing world? Review of Income and Wealth, 40, 359-376.

Christiaensen, L., Demery, L., \& Paternostro, S. (2003). Macro and micro perspectives of growth and poverty in Africa. The World Bank Economic Review, 17, 317-347.

Claessens, S., \& Feijen, E. (2007). Financial sector development and the millennium development goals. World Bank Publications.

Clarke, G., Xu, L. C., \& Zou, H.-F. (2013). Finance and Income Inequality: Test of Alternative Theories. Annals of Economics and Finance, 14, 491-516.

Coleman, B. E. (2006). Microfinance in Northeast Thailand: Who benefits and how much? World Development, 34, 1612-1638.

Cotler, P., \& Woodruff, C. (2008). The impact of short-term credit on microenterprises: evidence from the Fincomun-Bimbo program in Mexico. Economic Development and Cultural Change, 56, 829-849.

Datt, G., \& Ravallion, M. (1992). Growth and redistribution components of changes in poverty measures: A decomposition with applications to Brazil and India in the 1980s. Journal of development economics, 38, 275-295.

Demery, L., \& Squire, L. (1996). Macroeconomic adjustment and poverty in Africa: an emerging picture. The World Bank Research Observer, 11, 39-59.

Dollar, D., Kleineberg, T., \& Kraay, A. (2013). Growth still is good for the poor. LIS Working Paper Series.

Dollar, D., \& Kraay, A. (2002). Growth is Good for the Poor. Journal of economic growth, 7, 195-225.

Easterly, W., \& Fischer, S. (2001). Inflation and the Poor. Journal of Money, Credit and Banking, 160-178.

Easterly, W., Islam, R., \& Stiglitz, J. E. (2001). Shaken and stirred: explaining growth volatility. Annual World Bank conference on development economics, 2001, 211.

Favarra, G. (2003). An empirical reassessment of the relationship between finance and growth. International Monetary Fund.

Fowowe12, B., \& Abidoye, B. (2012). A quantitative assessment of the effect of financial development on poverty in African countries.

Galor, O., \& Zeira, J. (1993). Income distribution and macroeconomics. The review of economic studies, 60, 35-52.

Goldsmith, R. W. (1969). Financial structure and development. Yale University Press, New Haven.

Greenwood, J., \& Jovanovic, B. (1989). Financial development, growth, and the distribution of income. National Bureau of Economic Research. 
Group, W. B. (2012). World Development Indicators 2012. World Bank Publications.

Guillaumont Jeanneney, S., \& Kpodar, K. (2007). Développement financier, instabilité financière et croissance économique. Economie \& prévision, 87-111.

Gujarati, D. N. (2012). Basic econometrics. Tata McGraw-Hill Education.

Haber, S. (2005). Mexico's experiments with bank privatization and liberalization, 1991-2003. Journal of Banking \& Finance, 29, 2325-2353.

Honohan, P. (2004). Financial development, growth, and poverty: how close are the links?

Honohan, P., \& Beck, T. (2007). Making finance work for Africa. World Bank Publications.

Husain, I. (2004). Financial sector reforms and pro-poor growth: Case study of Pakistan. Presidential Address at the Annual General Meeting of the Institute of Bankers Pakistan, Karachi, 21st February, 2004.

Jalilian, H., \& Kirkpatrick, C. (2002). Financial development and poverty reduction in developing countries. International Journal of Finance \& Economics, 7, 97-108.

Jalilian, H., \& Kirkpatrick, C. (2005). Does financial development contribute to poverty reduction? Journal of Development Studies, 41, 636-656.

Jappelli, T., \& Pagano, M. (1994). Saving, growth, and liquidity constraints. The Quarterly Journal of Economics, 83-109.

Jeanneney, S. G., \& Kpodar, K. (2011). Financial development and poverty reduction: Can there be a benefit without a cost? The Journal of Development Studies, 47, 143-163.

Kanbur, R. (2001). Economic policy, distribution and poverty: the nature of disagreements. World development, 29, 1083-1094.

Keynes, J. M. (1937). Alternative theories of the rate of interest. The Economic Journal, 241-252.

Khandker, S. R. (2005). Microfinance and poverty: Evidence using panel data from Bangladesh. The World Bank Economic Review, 19, 263-286.

King, R. G., \& Levine, R. (1993). Finance, entrepreneurship and growth. Journal of monetary Economics, 32, 513-542.

King, R. G., \& Levine, R. (2004). Finance and Growth Schumpter Might Be Right. World Bank Publications.

Kpodar, K., \& Singh, R. J. (2011). Does financial structure matter for poverty? evidence from developing countries.

Kuznets, S. (1955). Economic growth and income inequality. The American economic review, 1-28.

Levine, R. (2005). Finance and growth: theory and evidence. Handbook of economic growth, 1, 865-934.

Levine, R. (2008). Finance and the Poor. The Manchester School, 76, 1-13.

Levine, R., Loayza, N., \& Beck, T. (2000). Financial intermediation and growth: Causality and causes. Journal of monetary Economics, 46, 31-77.

Lin, J. (2009). Walk, don't run'. The Economist, 11.

Lipton, M., \& Ravallion, M. (1993). Poverty and policy. World Bank Publications.

Loayza, N. V., \& Ranciere, R. (2006). Financial development, financial fragility, and growth. Journal of Money, Credit and Banking, 1051-1076.

Lucas, R. (1998). On the mechanics of economic development. Econometric Society Monographs, 29, 61-70.

Lustig, N., Arias, O., \& Rigolini, J. (2002). Poverty reduction and economic growth: A two-way causality. Inter-American Development Bank.

Mckinnon, R. I. (1973). Money and capital in economic development. Brookings Institution Press.

Milanović, B. (2010). The Haves and the Have-Nots: A brief and idiosyncratic history of global inequality. Basic books.

Miller, M. H. (1998). Financial markets and economic growth. Journal of Applied Corporate Finance, 11, 8-15.

Montgomery, H. (2006). Serving the poorest of the poor: the poverty impact of the Khushhali Bank's microfinance lending in Pakistan. Poverty strategies in Asia: a growth plus approach, 222. 
Morduch, J. (2000). The microfinance schism. World development, 28, 617-629.

Mosley, P., \& Hulme, D. (1998). Microenterprise finance: is there a conflict between growth and poverty alleviation? World development, 26, 783-790.

Odhiambo, N. M. (2009). Finance-growth-poverty nexus in South Africa: a dynamic causality linkage. The Journal of Socio-Economics, 38, 320-325.

Odhiambo, N. M. (2010). Is financial development a spur to poverty reduction? Kenya's experience. Journal of Economic Studies, 37, 343-353.

Patrick, H. T. (1966). Financial development and economic growth in underdeveloped countries. Economic development and Cultural change, 174-189.

Perez-Moreno, S. (2011). Financial development and poverty in developing countries: a causal analysis. Empirical Economics, 41, 57-80.

Pitt, M. M., \& Khandker, S. R. (1998). The impact of group-based credit programs on poor households in Bangladesh: Does the gender of participants matter? Journal of political economy, 106, 958-996.

Rahman, M. H. (2004). Financial Development-Economic Growth Nexus: A Case Study of Bangladesh. The Bangladesh Development Studies, 113-128.

Ravallion, M. (2007). Economic growth and poverty reduction. Do poor countries need to worry about inequality. October, 2020.

Ravi Kanbur, S. (1987). Structural adjustment, macroeconomic adjustment and poverty: A methodology for analysis. World Development, 15, 1515-1526.

Romer, P. M. (1986). Increasing returns and long-run growth. The journal of political economy, 1002-1037.

Roodman, D., \& Morduch, J. (2009). The impact of microcredit on the poor in Bangladesh: Revisiting the evidence. Center for Global Development Working Paper, 174.

Schumpeter, J. A. (1934). The theory of economic development: An inquiry into profits, capital, credit, interest, and the business cycle. Transaction Publishers.

Shaw, E. S. (1973). Financial deepening in economic development. New York: Oxford University Press.

Solow, R. M. (1956). A contribution to the theory of economic growth. The quarterly journal of economics, 65-94.

Somavia, J. (2003). Working out of poverty: report of the Director-General. International Labour Office.

Stiglitz, J. E. (1993). The role of the state in financial markets. Institute of Economics, Academia Sinica.

Stiglitz, J. E., \& Weiss, A. (1981). Credit rationing in markets with imperfect information. The American economic review, 393-410.

Thoma, M. (2009). Lin Roundtable: Small Banks Need Help. Free Exchange, Economist. com blogs.

Townsend, R. M., \& Ueda, K. (2006). Financial deepening, inequality, and growth: a model-based quantitative evaluation. The Review of Economic Studies, 73, 251-293.

Uddin, G. S., Shahbaz, M., Arouri, M., \& Teulon, F. (2014). Financial development and poverty reduction nexus: A cointegration and causality analysis in Bangladesh. Economic Modelling, 36, 405-412.

UNDP. (2013). The 2013 human development report-"The rise of the south: human progress in a diverse world".

Van Wijnbergen, S. (1982). Stagflationary effects of monetary stabilization policies: A quantitative analysis of South Korea. Journal of Development Economics, 10, 133-169.

World, B. (2001). World development report 2000/2001: attacking poverty. World development report 2000/2001: attacking poverty. 


\section{Appendix A. Result of Normality Test}

Shapiro-Wilk W Test for Normality

\begin{tabular}{lcl}
\hline Variables & Z value & Result \\
\hline Log of income of the poorest $20 \%$ & 2.911 & Normal \\
\hline Log GDP per capita $(\mathrm{y})$ & 1.68 & Normal \\
\hline Poverty gap & 2.34 & Normal \\
\hline M3/GDP & 2.27 & Normal \\
\hline Instability of M3/GDP & 5.88 & Normal \\
\hline Inflation & 5.87 & Normal \\
\hline Growth & 1.98 & Normal \\
\hline Instability in growth & 1.50 & Normal \\
\hline Primary school enrolment & 1.34 & Normal \\
\hline Government consumption & 1.08 & Normal \\
\hline Log of Trade openness & 2.80 & Normal \\
\hline
\end{tabular}

Appendix B. Estimated Coefficients using OLS and GMM Methods

Table 1. Impact of Financial Development (M3/GDP) and Financial Instability on the Average Income of the Poor

\begin{tabular}{|c|c|c|c|c|c|c|c|c|c|}
\hline \multirow{2}{*}{$\begin{array}{l}\text { Dependent } \\
\text { variable: } \\
\text { Log of income of } \\
\text { the poorest } 20 \%\end{array}$} & \multicolumn{3}{|c|}{ OLS estimator } & \multicolumn{6}{|c|}{ GMM estimator } \\
\hline & (1) & (2) & (3) & (4) & (5) & (6) & (7) & (8) & (9) \\
\hline $\begin{array}{l}\text { Log GDP per } \\
\text { capita (y) }\end{array}$ & & $\begin{array}{c}0.062 \\
(10.42)^{* * *}\end{array}$ & $\begin{array}{c}0.0659 \\
(9.25)^{* * *} \\
\end{array}$ & $\begin{array}{c}0.062 \\
(10.99)^{* * *}\end{array}$ & $\begin{array}{c}0.065 \\
(9.92)^{* * *}\end{array}$ & $\begin{array}{c}0.064 \\
(9.78)^{* * *} \\
\end{array}$ & $\begin{array}{c}0.065 \\
(9.57)^{* * *} \\
\end{array}$ & $\begin{array}{c}0.092 \\
(26.88) \\
\end{array}$ & $\begin{array}{c}0.079 \\
(15.9)^{* * *}\end{array}$ \\
\hline M3/GDP & $\begin{array}{c}0.628 \\
(20.97)^{* * *}\end{array}$ & $\begin{array}{c}0.041 \\
(5.73)^{* * *}\end{array}$ & $\begin{array}{c}0.205 \\
(3.67)^{* * *}\end{array}$ & $\begin{array}{c}0.235 \\
(6.03)^{* * *}\end{array}$ & $\begin{array}{c}0.661 \\
(3.94)^{* * *}\end{array}$ & $\begin{array}{c}0.197 \\
(3.87) * * *\end{array}$ & $\begin{array}{l}0.146 \\
(3.18)\end{array}$ & $\begin{array}{c}0.065 \\
(2.92)^{* *}\end{array}$ & $\begin{array}{c}0.227 \\
(4.03)^{* * *}\end{array}$ \\
\hline $\begin{array}{l}\text { Instability of } \\
\text { M3/GDP }\end{array}$ & & & $\begin{array}{l}-0.662 \\
(1.65)^{*}\end{array}$ & & $\begin{array}{c}-0.205 \\
(1.97)^{* *}\end{array}$ & $\begin{array}{l}-0.872 \\
(1.93)^{*}\end{array}$ & $\begin{array}{l}-0.246 \\
(0.32)\end{array}$ & $\begin{array}{l}-0.940 \\
(1.77)^{*}\end{array}$ & $\begin{array}{l}-0.294 \\
(0.40)\end{array}$ \\
\hline Inflation & & $\begin{array}{c}-0.00506 \\
(.010) \\
\end{array}$ & $\begin{array}{l}-.033 \\
(0.81) \\
\end{array}$ & $\begin{array}{l}-0.005 \\
(0.53) \\
\end{array}$ & $\begin{array}{l}-.033 \\
(0.87) \\
\end{array}$ & $\begin{array}{l}-0.043 \\
(1.24) \\
\end{array}$ & $\begin{array}{l}-0.017 \\
(0.38) \\
\end{array}$ & $\begin{array}{c}-0.0037 \\
(1.10) \\
\end{array}$ & $\begin{array}{l}-0.022 \\
(0.65) \\
\end{array}$ \\
\hline Growth & & & & & & $\begin{array}{l}0.219 \\
(1.15)\end{array}$ & & & \\
\hline $\begin{array}{l}\text { Instability in } \\
\text { growth }\end{array}$ & & & & & & & $\begin{array}{c}-1.840 \\
(2.39)^{* *}\end{array}$ & & \\
\hline $\begin{array}{l}\text { M3/GDP*Number } \\
\text { of bank branches per } \\
\mathrm{km}^{2}\end{array}$ & & & & & & & & $\begin{array}{l}0.0003 \\
(1.11)\end{array}$ & \\
\hline$(\mathrm{M} 3 / \mathrm{GDP})^{*} \mathrm{y}$ & & & & & & & & & $\begin{array}{c}-.0282 \\
(3.54)^{* * *}\end{array}$ \\
\hline Constant & $\begin{array}{l}-7.539549 \\
(7.85)^{* * *}\end{array}$ & $\begin{array}{l}-0.306 \\
(0.30)\end{array}$ & $\begin{array}{l}-2.036 \\
(0.98)\end{array}$ & $\begin{array}{l}-0.306 \\
(0.32)\end{array}$ & $\begin{array}{l}-2.036 \\
(1.05)\end{array}$ & $\begin{array}{c}-2.325 \\
(.29)\end{array}$ & $\begin{array}{c}-9.567 \\
(3.79)^{* * *}\end{array}$ & $\begin{array}{l}-5.201 \\
(0.72)\end{array}$ & $\begin{array}{l}-0.211 \\
(0.06)\end{array}$ \\
\hline Observations & 40 & 40 & 40 & 40 & 40 & 38 & 38 & 9 & 38 \\
\hline $\mathrm{R}^{2}$ & 0.93 & 0.97 & 0.97 & & & & & & \\
\hline $\begin{array}{l}\text { Durbin-Watson } \\
\text { d-statistic }\end{array}$ & $\begin{array}{c}1.285 \\
\text { (no auto) }\end{array}$ & $\begin{array}{r}1.146 \\
\text { (no auto) }\end{array}$ & $\begin{array}{c}1.315 \\
\text { (no auto) }\end{array}$ & $\begin{array}{c}1.146 \\
\text { (no auto) }\end{array}$ & $\begin{array}{c}1.316 \\
\text { (no auto) }\end{array}$ & $\begin{array}{c}1.379 \\
\text { (no auto) }\end{array}$ & $\begin{array}{c}1.383 \\
\text { (no auto) }\end{array}$ & $\begin{array}{c}0.741 \\
\text { (no auto) }\end{array}$ & $\begin{array}{c}1.326 \\
\text { (no auto) }\end{array}$ \\
\hline
\end{tabular}

Notes: the absolute values of robust $\mathrm{t}$ statistics are in the brackets, where, $* * *$ indicates significant at $1 \%$; $* *$ indicates significant at $5 \%$; and, * indicates significant at $10 \%, \&$ 'no auto' stands for no autocollinearity. 
Table 2. Impact of Financial Development (Credit/GDP) and Financial Instability on the Average Income of the Poor

\begin{tabular}{|c|c|c|c|c|c|c|c|c|c|}
\hline \multirow{2}{*}{$\begin{array}{l}\text { Dependent variable: } \\
\text { Log of income of the } \\
\text { poorest } 20 \%\end{array}$} & \multicolumn{3}{|c|}{ OLS estimator } & \multicolumn{6}{|c|}{ GMM estimator } \\
\hline & (1) & (2) & (3) & (4) & (5) & (6) & (7) & (8) & (9) \\
\hline $\begin{array}{l}\text { Log GDP per capita } \\
\text { (y) }\end{array}$ & & $\begin{array}{c}0.042 \\
(4.97) * * *\end{array}$ & $\begin{array}{c}0.044 \\
(4.90)^{* * *}\end{array}$ & $\begin{array}{c}0.0437 \\
(5.78)^{* * *}\end{array}$ & $\begin{array}{c}0.044 \\
(5.26)^{* * *}\end{array}$ & $\begin{array}{c}0.043 \\
(5.20)^{* * *}\end{array}$ & $\begin{array}{c}0.046 \\
(2.03)^{* *}\end{array}$ & $\begin{array}{c}0.086 \\
(30.8)^{* * *}\end{array}$ & $\begin{array}{c}0.043 \\
(4.20)^{* * *}\end{array}$ \\
\hline Credit/GDP & $\begin{array}{c}.5345808 \\
(19.34)^{* * *}\end{array}$ & $\begin{array}{c}0.439 \\
(6.87)^{* * *}\end{array}$ & $\begin{array}{c}0.442 \\
(6.61)^{* * *}\end{array}$ & $\begin{array}{c}0.429 \\
(7.88)^{* * *}\end{array}$ & $\begin{array}{c}0.442 \\
(7.09)^{* * *}\end{array}$ & $\begin{array}{c}0.441 \\
(7.23)^{* * *}\end{array}$ & $\begin{array}{c}0.403 \\
(1.56)^{*}\end{array}$ & $\begin{array}{l}0.032 \\
(1.52)\end{array}$ & $\begin{array}{c}0.448 \\
(7.05)^{* * *}\end{array}$ \\
\hline $\begin{array}{l}\text { Instability of } \\
\text { Credit/GDP }\end{array}$ & & & $\begin{array}{l}-2.062 \\
(0.93)\end{array}$ & & $\begin{array}{l}-2.062 \\
(0.16)\end{array}$ & $\begin{array}{l}-2.666 \\
(1.33)\end{array}$ & $\begin{array}{l}-2.486 \\
(1.12)\end{array}$ & $\begin{array}{l}-.602 \\
(1.020\end{array}$ & $\begin{array}{l}-2.083 \\
(1.03)\end{array}$ \\
\hline Inflation & & $\begin{array}{c}-0.0057 \\
(0.75)\end{array}$ & $\begin{array}{l}-.0048 \\
(0.15)\end{array}$ & $\begin{array}{l}-0.005 \\
(0.79)\end{array}$ & $\begin{array}{c}-0.0048 \\
(1.00)\end{array}$ & $\begin{array}{l}-0.006 \\
(0.24)\end{array}$ & $\begin{array}{l}-0.005 \\
(0.23)\end{array}$ & $\begin{array}{l}-0.002 \\
(0.67)\end{array}$ & $\begin{array}{c}-0.0048 \\
(0.16)\end{array}$ \\
\hline Growth & & & & & & $\begin{array}{l}0.146 \\
(1.33)\end{array}$ & & & \\
\hline Instability in growth & & & & & & & $\begin{array}{l}-0.280 \\
(0.17) \\
\end{array}$ & & \\
\hline $\begin{array}{l}\text { Credit/GDP*Number } \\
\text { of bank branches per } \\
\mathrm{km}^{2}\end{array}$ & & & & & & & & $\begin{array}{l}0.0003 \\
(1.91)^{*}\end{array}$ & \\
\hline$($ Credit/GDP)*y & & & & & & & & & $\begin{array}{l}.00005 \\
(0.08) \\
\end{array}$ \\
\hline Constant & $\begin{array}{c}10.77214 \\
(11.37)^{* * *} \\
\end{array}$ & $\begin{array}{c}5.029 \\
(2.94)^{* * *}\end{array}$ & $\begin{array}{c}6.982 \\
(2.58)^{* * *}\end{array}$ & $\begin{array}{c}4.936 \\
(3.10)^{* * *} \\
\end{array}$ & $\begin{array}{c}6.982 \\
(2.77)^{* *}\end{array}$ & $\begin{array}{c}7.203 \\
(2.95)^{* *}\end{array}$ & $\begin{array}{l}8.164 \\
(1.42)\end{array}$ & $\begin{array}{l}0.0003 \\
(1.91)^{*}\end{array}$ & $\begin{array}{c}7.099 \\
(2.48)^{* *}\end{array}$ \\
\hline Observations & 40 & 40 & 40 & 40 & 40 & 38 & 38 & 9 & 38 \\
\hline $\mathrm{R}^{2}$ & 0.91 & 0.956 & 0.957 & & & & & & \\
\hline $\begin{array}{l}\text { Durbin-Watson } \\
\text { d-statistic }\end{array}$ & $\begin{array}{c}1.217 \\
\text { (no auto) }\end{array}$ & $\begin{array}{c}1.272 \\
\text { (no auto) }\end{array}$ & $\begin{array}{c}1.293 \\
\text { (no auto) }\end{array}$ & $\begin{array}{c}1.310 \\
\text { (no auto) }\end{array}$ & $\begin{array}{c}1.301 \\
\text { (no auto) }\end{array}$ & $\begin{array}{c}1.270 \\
\text { (no auto) }\end{array}$ & $\begin{array}{r}1.281 \\
\text { (no aut) }\end{array}$ & $\begin{array}{c}0.830 \\
\text { (no auto) }\end{array}$ & $\begin{array}{c}1.276 \\
\text { (no auto) }\end{array}$ \\
\hline
\end{tabular}

Table 3. Impact of Financial Development (M3/GDP) and Financial Instability on the Headcount Poverty rate

\begin{tabular}{|c|c|c|c|c|c|c|c|c|c|}
\hline $\begin{array}{l}\text { Dependent } \\
\text { variable: } \\
\text { Poverty } \\
\text { headcount ratio }\end{array}$ & \multicolumn{3}{|c|}{ OLS estimator } & \multicolumn{6}{|c|}{ GMM estimator } \\
\hline $\begin{array}{l}\text { Log GDP per } \\
\text { capita (y) }\end{array}$ & & $\begin{array}{c}-0.062 \\
(3.66) * * *\end{array}$ & $\begin{array}{c}-0.068 \\
(5.09)^{* * *}\end{array}$ & $\begin{array}{c}-0.062 \\
(3.90)^{* * *}\end{array}$ & $\begin{array}{c}-0.068 \\
(5.52)^{* * *}\end{array}$ & $\begin{array}{c}-0.063 \\
(4.24)^{* * *}\end{array}$ & $\begin{array}{c}-0.055 \\
(3.84)^{* * *}\end{array}$ & $\begin{array}{l}0.206 \\
(1.17)\end{array}$ & $\begin{array}{c}-0.045 \\
(2.82)^{* *}\end{array}$ \\
\hline M3/GDP & $\begin{array}{c}-0.165 \\
(6.36)^{* * * *}\end{array}$ & $\begin{array}{c}-0.223 \\
(2.00)^{* *}\end{array}$ & $\begin{array}{c}-0.172 \\
(1.81)^{* *}\end{array}$ & $\begin{array}{c}-0.223 \\
(2.14)^{* *}\end{array}$ & $\begin{array}{c}-0.172 \\
(1.96)^{* *}\end{array}$ & $\begin{array}{c}-0.171 \\
(2.01)^{* *}\end{array}$ & $\begin{array}{l}-0.107 \\
(1.38)\end{array}$ & $\begin{array}{l}-0.810 \\
(1.64)^{*}\end{array}$ & $\begin{array}{l}-0.062 \\
(0.86)\end{array}$ \\
\hline $\begin{array}{l}\text { Instability of } \\
\text { M3/GDP }\end{array}$ & & & $\begin{array}{c}9.746 \\
(3.04) * * *\end{array}$ & & $\begin{array}{c}9.744 \\
(3.30)^{* * *}\end{array}$ & $\begin{array}{c}8.601 \\
(2.79)^{* *}\end{array}$ & $\begin{array}{c}5.704 \\
(1.78)^{*}\end{array}$ & $\begin{array}{l}9.455 \\
(1.59)\end{array}$ & $\begin{array}{c}8.071 \\
(2.67)^{*}\end{array}$ \\
\hline Inflation & & $\begin{array}{l}0.206 \\
(1.33)\end{array}$ & $\begin{array}{l}0.193 \\
(1.13)\end{array}$ & $\begin{array}{c}0.203 \\
(2.14)^{* *}\end{array}$ & $\begin{array}{l}0.193 \\
(1.22)\end{array}$ & $\begin{array}{l}0.180 \\
(1.10)\end{array}$ & $\begin{array}{l}0.138 \\
(0.77)\end{array}$ & $\begin{array}{l}0.092 \\
(0.92)\end{array}$ & $\begin{array}{c}0.266 \\
(1.64)^{*}\end{array}$ \\
\hline
\end{tabular}




\begin{tabular}{|c|c|c|c|c|c|c|c|c|c|}
\hline Growth & & & & & & $\begin{array}{l}-0.610 \\
(1.11)\end{array}$ & & & \\
\hline $\begin{array}{l}\text { Instability in } \\
\text { growth }\end{array}$ & & & & & & & $\begin{array}{c}5.347 \\
(3.199)^{* * *}\end{array}$ & & \\
\hline $\begin{array}{l}\text { M3/GDP*Number } \\
\text { of bank branches } \\
\text { per km² }\end{array}$ & & & & & & & & $\begin{array}{l}-.0025 \\
(0.22)\end{array}$ & \\
\hline$(\mathrm{M} 3 / \mathrm{GDP})^{*} \mathrm{y}$ & & & & & & & & & $\begin{array}{c}-0.038 \\
(2.87)^{* *}\end{array}$ \\
\hline Constant & $\begin{array}{c}23.35 \\
(18.06)^{* * *}\end{array}$ & $\begin{array}{c}76.31 \\
(28.01)^{* * *}\end{array}$ & $\begin{array}{c}106.36 \\
(10.28)^{* * *}\end{array}$ & $\begin{array}{c}76.31 \\
(29.88)\end{array}$ & $\begin{array}{c}106.36 \\
(11.16)^{* * *}\end{array}$ & $\begin{array}{c}104.20 \\
(10.63)^{* * *}\end{array}$ & $\begin{array}{c}65.24 \\
(3.90)^{* * *}\end{array}$ & $\begin{array}{l}318.94 \\
(1.21)\end{array}$ & $\begin{array}{c}93.36 \\
(8.07)^{* * *}\end{array}$ \\
\hline Observations & 33 & 33 & 33 & 33 & 33 & 33 & 33 & 9 & 33 \\
\hline $\mathrm{R}^{2}$ & 0.5048 & 0.9209 & 0.9429 & & & & & & \\
\hline $\begin{array}{l}\text { Durbin-Watson } \\
\text { d-statistic }\end{array}$ & $\begin{array}{c}1.217 \\
\text { (no auto) }\end{array}$ & $\begin{array}{c}1.274 \\
\text { (no auto) }\end{array}$ & $\begin{array}{c}1.258 \\
\text { (no auto) }\end{array}$ & $\begin{array}{c}1.231 \\
\text { (no auto) }\end{array}$ & $\begin{array}{c}1.271 \\
\text { (no auto) }\end{array}$ & $\begin{array}{c}1.294 \\
\text { (no auto) }\end{array}$ & $\begin{array}{c}1.230 \\
\text { (no auto) }\end{array}$ & $\begin{array}{c}0.792 \\
\text { (no auto) }\end{array}$ & $\begin{array}{c}1.219 \\
\text { (no auto) }\end{array}$ \\
\hline
\end{tabular}

Notes: the absolute values of robust $\mathrm{t}$ statistics are in the brackets, where, $* * *$ indicates significant at $1 \%$; $* *$ indicates significant at 5\%; and, * indicates significant at 10\%, \& 'no auto' stands for no autocollinearity.

Table 4. Impact of Financial Development (Credit/GDP) and Financial Instability on the Headcount Poverty rate

\begin{tabular}{|c|c|c|c|c|c|c|c|c|c|}
\hline \multirow{2}{*}{$\begin{array}{l}\text { Dependent variable: } \\
\text { Poverty headcount } \\
\text { ratio }\end{array}$} & \multicolumn{4}{|c|}{ OLS estimator } & \multicolumn{5}{|c|}{ GMM estimator } \\
\hline & (1) & (2) & (3) & (4) & (5) & (6) & (7) & (8) & (9) \\
\hline $\begin{array}{l}\text { Log GDP per capita } \\
\text { (y) }\end{array}$ & & $\begin{array}{c}-2.49 \mathrm{e}-10 \\
(1.34)\end{array}$ & $\begin{array}{c}-2.63 \mathrm{e}-10 \\
(1.25)\end{array}$ & $\begin{array}{l}-0.016 \\
(0.027)\end{array}$ & $\begin{array}{l}-0.013 \\
(0.40)\end{array}$ & $\begin{array}{l}-0.009 \\
(0.27)\end{array}$ & $\begin{array}{c}-0.070 \\
(2.17)^{* *}\end{array}$ & $\begin{array}{l}-0.021 \\
(1.64)^{*}\end{array}$ & $\begin{array}{l}-0.006 \\
(0.21)\end{array}$ \\
\hline Credit/GDP & $\begin{array}{c}-0.807 \\
(18.57)^{* * *}\end{array}$ & $\begin{array}{l}-0.371 \\
(1.21)\end{array}$ & $\begin{array}{l}-0.335 \\
(0.89)\end{array}$ & $\begin{array}{c}-0.665 \\
(2.89)^{* *}\end{array}$ & $\begin{array}{c}-.696 \\
(2.07) * *\end{array}$ & $\begin{array}{c}-691 \\
(2.07)^{* *}\end{array}$ & $\begin{array}{l}-0.163 \\
(0.46)\end{array}$ & $\begin{array}{c}-0.213 \\
(2.08) * *\end{array}$ & $\begin{array}{l}-0.457 \\
(1.58)\end{array}$ \\
\hline $\begin{array}{l}\text { Instability of } \\
\text { Credit/GDP }\end{array}$ & & & $\begin{array}{l}1.228 \\
(0.26)\end{array}$ & & $\begin{array}{l}1.116 \\
(0.19)\end{array}$ & $\begin{array}{l}4.978 \\
(.59)\end{array}$ & $\begin{array}{l}7.049 \\
(1.35)\end{array}$ & $\begin{array}{c}9.879 \\
(2.09)^{* *}\end{array}$ & $\begin{array}{l}0.904 \\
(0.15)\end{array}$ \\
\hline Inflation & & $\begin{array}{l}0.102 \\
(0.65)\end{array}$ & $\begin{array}{l}0.097 \\
(0.61)\end{array}$ & $\begin{array}{l}0.115 \\
(0.70)\end{array}$ & $\begin{array}{l}0.116 \\
(.71)\end{array}$ & $\begin{array}{l}0.117 \\
(0.68)\end{array}$ & $\begin{array}{c}0.339 \\
(2.02)^{* *}\end{array}$ & $\begin{array}{l}0.031 \\
(0.15)\end{array}$ & $\begin{array}{l}0.194 \\
(1.31)\end{array}$ \\
\hline Growth & & & & & & $\begin{array}{l}-1.075 \\
(1.39) \\
\end{array}$ & & & \\
\hline Instability in growth & & & & & & & $\begin{array}{c}11.396 \\
(4.10)^{* * * *}\end{array}$ & & \\
\hline $\begin{array}{l}\text { Credit/GDP*Number } \\
\text { of bank branches per } \\
\mathrm{km}^{2}\end{array}$ & & & & & & & & $\begin{array}{l}-0.010 \\
(1.41)\end{array}$ & \\
\hline$($ Credit/GDP)*y & & & & & & & & & $\begin{array}{c}-0.046 \\
(3.54)^{* * *}\end{array}$ \\
\hline Constant & $\begin{array}{c}67.14808 \\
(61.94)^{* * *} \\
\end{array}$ & $\begin{array}{c}67.099 \\
(34.11)^{* * *}\end{array}$ & $\begin{array}{l}68.325 \\
(13.13) \\
\end{array}$ & $\begin{array}{c}68.557 \\
(16.90)^{* * *} \\
\end{array}$ & $\begin{array}{c}67.18 \\
(6.90)^{* * *} \\
\end{array}$ & $\begin{array}{c}66.255 \\
(6.27)^{* * *} \\
\end{array}$ & $\begin{array}{r}11.442 \\
(0.70) \\
\end{array}$ & $\begin{array}{c}30.276 \\
(0.76) \\
\end{array}$ & $\begin{array}{c}61.926 \\
(6.32)^{* *}\end{array}$ \\
\hline Observations & 33 & 33 & 33 & 33 & 33 & 33 & 33 & 9 & 33 \\
\hline $\mathrm{R}^{2}$ & 0.9259 & 0.9307 & 0.9308 & & & & & & \\
\hline $\begin{array}{l}\text { Durbin-Watson } \\
\text { d-statistic }\end{array}$ & $\begin{array}{c}1.972 \\
\text { (no auto) }\end{array}$ & $\begin{array}{c}1.319 \\
\text { (no auto) }\end{array}$ & $\begin{array}{c}1.294 \\
\text { (no auto) }\end{array}$ & $\begin{array}{c}1.721 \\
\text { (no auto) }\end{array}$ & $\begin{array}{c}1.281 \\
\text { (no auto) }\end{array}$ & $\begin{array}{c}1.261 \\
\text { (no auto) }\end{array}$ & $\begin{array}{c}1.264 \\
\text { (no auto) }\end{array}$ & $\begin{array}{c}0.721 \\
\text { (no auto) }\end{array}$ & $\begin{array}{c}1.296 \\
\text { (no auto) }\end{array}$ \\
\hline
\end{tabular}

Notes: the absolute values of robust $t$ statistics are in the brackets, where, $* * *$ indicates significant at $1 \%$; $* *$ indicates significant at 5\%; and, * indicates significant at $10 \%, \&$ 'no auto' stands for no autocollinearity. 
Table 5. Impact of Financial Development (M3/GDP) and Financial Instability on Poverty Gap

\begin{tabular}{|c|c|c|c|c|c|c|c|c|c|}
\hline \multirow{2}{*}{$\begin{array}{l}\text { Dependent } \\
\text { variable: } \\
\text { Poverty gap }\end{array}$} & \multicolumn{3}{|c|}{ OLS estimator } & & \multicolumn{5}{|c|}{ GMM estimator } \\
\hline & (1) & (2) & (3) & (4) & (5) & (6) & (7) & (8) & (9) \\
\hline $\begin{array}{l}\text { Log GDP per } \\
\text { capita }(y)\end{array}$ & & $\begin{array}{c}-0.026 \\
(2.88)^{* *}\end{array}$ & $\begin{array}{c}-0.026 \\
(2.64)^{* *}\end{array}$ & $\begin{array}{c}-0.026 \\
(3.07)^{* * *}\end{array}$ & $\begin{array}{c}-0.026 \\
(2.87)^{* *}\end{array}$ & $\begin{array}{c}-0.033 \\
(3.91)^{* * *}\end{array}$ & $\begin{array}{c}-0.039 \\
(4.14)^{* * *}\end{array}$ & $\begin{array}{l}-0.021 \\
(0.20)\end{array}$ & $\begin{array}{c}-0.033 \\
(3.22)^{* * *}\end{array}$ \\
\hline M3/GDP & $\begin{array}{c}-0.165 \\
(6.36)^{* * *}\end{array}$ & $\begin{array}{l}-0.012 \\
(0.20)\end{array}$ & $\begin{array}{l}-0.012 \\
(0.18)\end{array}$ & $\begin{array}{c}-0.0123 \\
(0.21)\end{array}$ & $\begin{array}{c}-0.0128 \\
(0.20)\end{array}$ & $\begin{array}{l}-0.012 \\
(0.19)\end{array}$ & $\begin{array}{l}-0.051 \\
(0.91)\end{array}$ & $\begin{array}{l}-0.011 \\
(0.06)\end{array}$ & $\begin{array}{l}-0.020 \\
(0.25)\end{array}$ \\
\hline $\begin{array}{l}\text { Instability of } \\
\text { M3/GDP }\end{array}$ & & & $\begin{array}{l}0.091 \\
(1.74)^{*}\end{array}$ & & $\begin{array}{c}0.091 \\
(1.65)^{*}\end{array}$ & $\begin{array}{l}0.701 \\
(0.91)\end{array}$ & $\begin{array}{c}4.162 \\
(2.14)^{* *}\end{array}$ & $\begin{array}{l}2.679 \\
(0.69)\end{array}$ & $\begin{array}{l}0.595 \\
(0.30)\end{array}$ \\
\hline Inflation & & $\begin{array}{c}-0.411 \\
(4.41)^{* * *}\end{array}$ & $\begin{array}{c}-0.412 \\
(4.30)^{* * *}\end{array}$ & $\begin{array}{c}-0.411 \\
(4.70)^{* * *}\end{array}$ & $\begin{array}{c}-0.411 \\
(4.66)^{* * *}\end{array}$ & $\begin{array}{c}-.393 \\
(5.03)^{* * *}\end{array}$ & $\begin{array}{l}-0.077 \\
(0.76)\end{array}$ & $\begin{array}{l}-0.069 \\
(0.85)\end{array}$ & $\begin{array}{c}-.443 \\
(4.72)^{* * *}\end{array}$ \\
\hline Growth & & & & & & $\begin{array}{c}-0.858 \\
(2.23)^{* *}\end{array}$ & & & \\
\hline $\begin{array}{l}\text { Instability in } \\
\text { growth }\end{array}$ & & & & & & & $\begin{array}{c}-5.387 \\
(5.21)^{* * *}\end{array}$ & & \\
\hline $\begin{array}{l}\text { M3/GDP*Number } \\
\text { of bank branches } \\
\text { per km² }\end{array}$ & & & & & & & & $\begin{array}{c}-0.0005 \\
(0.09)\end{array}$ & \\
\hline$(\mathrm{M} 3 / \mathrm{GDP})^{*} \mathrm{y}$ & & & & & & & & & $\begin{array}{l}0.0115 \\
(0.332)\end{array}$ \\
\hline Constant & $\begin{array}{c}23.358 \\
(18.06)^{* * *}\end{array}$ & $\begin{array}{c}28.941 \\
(19.89)^{* * * *}\end{array}$ & $\begin{array}{c}29.223 \\
(3.87)^{* * *}\end{array}$ & $\begin{array}{c}28.941 \\
(21.22)^{* * *}\end{array}$ & $\begin{array}{c}29.223 \\
(4.20)^{* * *}\end{array}$ & $\begin{array}{c}32.262 \\
(5.17)^{* * *}\end{array}$ & $\begin{array}{c}70.657 \\
(6.81)^{* * *}\end{array}$ & $\begin{array}{l}77.84 \\
(0.48)\end{array}$ & $\begin{array}{c}33.136 \\
(4.50)^{* * *}\end{array}$ \\
\hline Observations & 33 & 33 & 33 & 33 & 33 & 33 & 33 & 9 & 33 \\
\hline $\mathrm{R}^{2}$ & 0.5048 & 0.722 & 0.7223 & & & & & & \\
\hline $\begin{array}{l}\text { Durbin-Watson } \\
\text { d-statistic }\end{array}$ & $\begin{array}{c}1.182 \\
\text { (no auto) }\end{array}$ & $\begin{array}{c}1.215 \\
\text { (no auto) }\end{array}$ & $\begin{array}{c}1.263 \\
\text { (no auto) }\end{array}$ & $\begin{array}{c}1.521 \\
\text { (no auto) }\end{array}$ & $\begin{array}{c}1.292 \\
\text { (no auto) }\end{array}$ & $\begin{array}{c}1.2531 \\
\text { (no auto) }\end{array}$ & $\begin{array}{c}1.271 \\
\text { (no auto) }\end{array}$ & $\begin{array}{c}0.821 \\
\text { (no auto) }\end{array}$ & $\begin{array}{c}1.242 \\
\text { (no auto) }\end{array}$ \\
\hline
\end{tabular}

Notes: the absolute values of robust $t$ statistics are in the brackets, where, $* * *$ indicates significant at $1 \%$; $* *$ indicates significant at 5\%; and, * indicates significant at $10 \%$.

Table 6. Impact of Financial Development (Credit/GDP) and Financial Instability on Poverty Gap

OLS estimator GMM estimator

\begin{tabular}{|c|c|c|c|c|c|c|c|c|c|}
\hline \multirow{2}{*}{$\begin{array}{l}\text { Dependent variable: } \\
\text { Poverty gap }\end{array}$} & \multirow[t]{2}{*}{ (1) } & \multirow[t]{2}{*}{ (2) } & \multirow[t]{2}{*}{ (3) } & \multirow[t]{2}{*}{ (4) } & \multirow[t]{2}{*}{ (5) } & \multirow[t]{2}{*}{ (6) } & \multirow[t]{2}{*}{ (7) } & \multirow[t]{2}{*}{ (8) } & \multirow[t]{2}{*}{ (9) } \\
\hline & & & & & & & & & \\
\hline \multirow{3}{*}{$\begin{array}{l}\text { Log GDP per capita } \\
\text { (y) }\end{array}$} & & -0.044 & -0.037 & -0.0447 & -0.0375 & -0.040 & -0.009 & -0.009 & -0.047 \\
\hline & & $(2.70)^{* *}$ & $(1.63)^{*}$ & $(2.89)^{* * *}$ & $(1.77)^{*}$ & $(2.04)^{* *}$ & $(0.36)$ & $(0.23)$ & (1.30) \\
\hline & -0.203 & -0.177 & -0.082 & -0.0177 & -0.082 & -0.079 & -0.339 & -0.697 & -0.078 \\
\hline Credit/GDP & $(6.56)^{* * *}$ & $(1.22)$ & $(0.34)$ & $(1.30)$ & $(0.37)$ & $(0.38)$ & $(1.11)$ & $(4.91)^{* * *}$ & $(0.36$ \\
\hline \multirow{2}{*}{$\begin{array}{l}\text { Instability of } \\
\text { Credit/GDP }\end{array}$} & & & 3.427 & & 3.427 & 1.127 & 0.517 & 1.741 & 3.554 \\
\hline & & & $(0.56)$ & & $(.61)$ & $(0.23)$ & $(0.10)$ & $(0.22)$ & $(0.66)$ \\
\hline
\end{tabular}




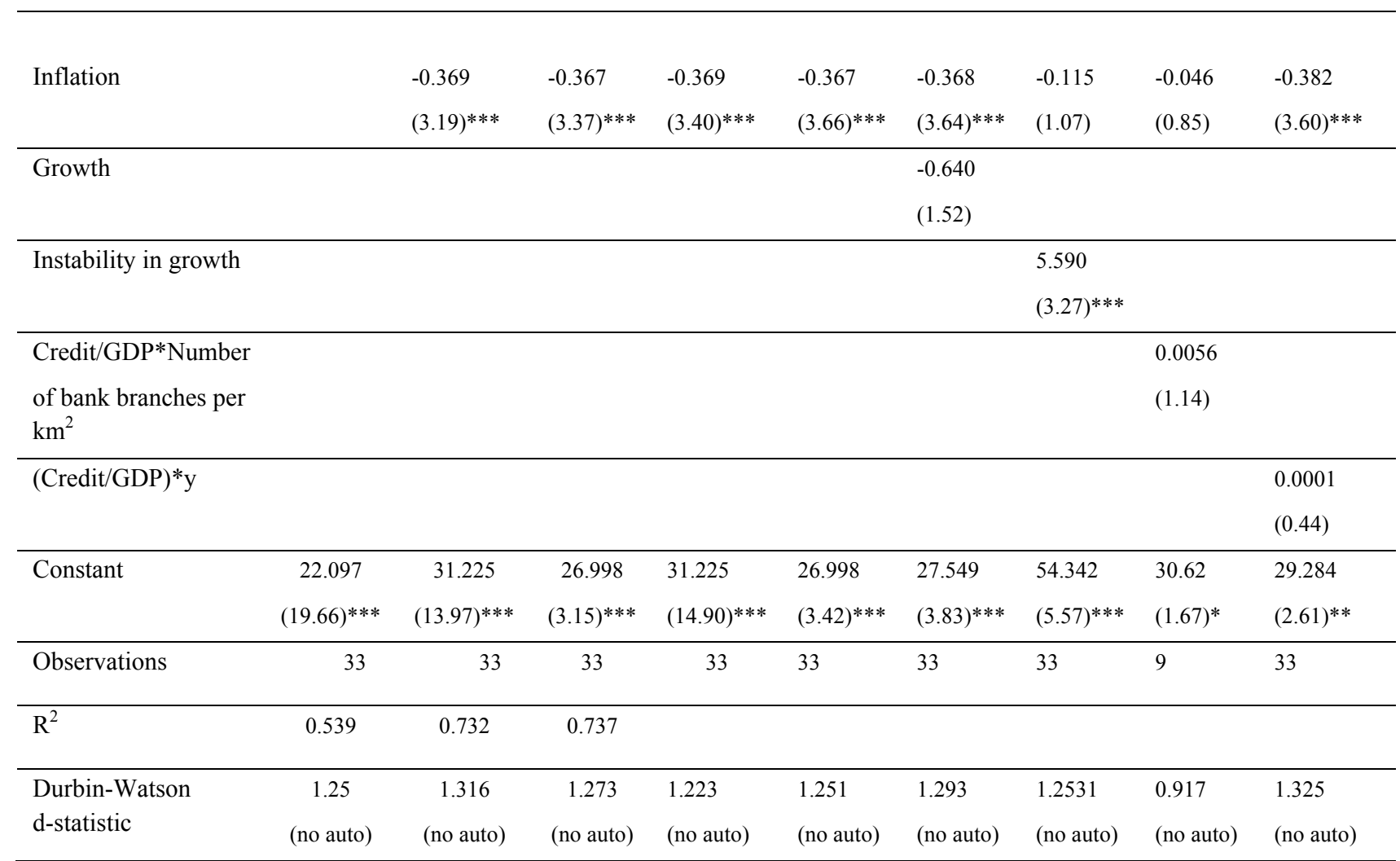

Notes: the absolute values of robust $\mathrm{t}$ statistics are in the brackets, where, *** indicates significant at $1 \%$; ** indicates significant at 5\%; and, * indicates significant at 10\%, \& 'no auto' stands for no autocollinearity.

Table 7. Impact of Financial Development, Financial Instability and other Macroeconomic indicators on Economic growth

\begin{tabular}{cc}
\hline Dependent variable: GDP growth & GMM Estimators \\
\hline Log of per capita & 27.735 \\
& $(2.66)^{* *}$ \\
\hline M3/GDP & 0.117 \\
& $(2.70)^{* *}$ \\
\hline Instability in M3/GDP & -0.856 \\
& $(1.79)^{*}$ \\
\hline Inflation rate & -0.856 \\
& $(1.79)^{*}$ \\
\hline Primary school enrolment & 0.131 \\
& $(1.69)^{*}$ \\
\hline Government consumption & -1.353 \\
& $(2.11)^{* *}$ \\
\hline Log of Trade openness & -5.545 \\
& $(1.49)$ \\
\hline Observations & 22 \\
\hline $\mathrm{R}^{2}$ & 0.742 \\
\hline
\end{tabular}

Notes: the absolute values of robust $\mathrm{t}$ statistics are in the brackets, where, ${ }^{* * *}$ indicates significant at $1 \%$;** indicates significant at 5\%; and, * indicates significant at $10 \%$. 
Appendix C. Name of the Variables and Data Sources

\begin{tabular}{|c|c|c|}
\hline Name of the variables & Description of the variable & Data sources \\
\hline $\begin{array}{l}\text { Log of average income } \\
\text { of the poorest } 20 \%\end{array}$ & $\begin{array}{l}\text { Aaverage per capita income (in } 2005 \\
\text { constant dollars) of the poorest } 20 \text { percent } \\
\text { of the population of Bangladesh }\end{array}$ & $\begin{array}{l}\text { World Poverty Database \& Dollar } \\
\text { and Kraay Database, } \\
\text { The World Bank }\end{array}$ \\
\hline $\begin{array}{l}\text { Poverty headcount } \\
\text { ratio }\end{array}$ & $\begin{array}{l}\text { The percentage of the population living } \\
\text { below the national poverty line measured by } \\
\text { the cost of basic needs (CNB) at } 2225 \\
\text { kilocalories food intake a day }\end{array}$ & $\begin{array}{c}\text { World Development Indicators, } \\
2014 \\
\text { The world Bank } \\
\& \\
\text { Bangladesh Bureau of Statistics }\end{array}$ \\
\hline Poverty gap & $\begin{array}{l}\text { Distance of the poor from the poverty line } \\
\text { defined by the World Bank as } \$ 1.25 \\
\text { income a day (PPP \%). }\end{array}$ & $\begin{array}{c}\text { PovStats and PovcalNet database, } \\
\text { The world Bank }\end{array}$ \\
\hline Log of per capita GDP & $\begin{array}{l}\text { Real GDP per capita of Bangladesh in } \\
\text { constant } 2005 \text { US } \$ \text { at PPP }\end{array}$ & $\begin{array}{c}\text { World Development Indicators, } \\
2014 \\
\text { The world Bank } \\
\end{array}$ \\
\hline M3/GDP & $\begin{array}{l}\text { The ratio of liquid assets of the financial } \\
\text { sector to GDP }\end{array}$ & $\begin{array}{l}\text { Global Financial Development } \\
\text { Indicators Database, } \\
\text { The World Bank }\end{array}$ \\
\hline Credit/GDP & $\begin{array}{l}\text { The ratio of private credit giving by } \\
\text { financial intermediaries to GDP }\end{array}$ & $\begin{array}{c}\text { Global Financial Development } \\
\text { Indicators Database, } \\
\text { The World Bank }\end{array}$ \\
\hline Growth & $\begin{array}{l}\text { Real GDP per capita growth of Bangladesh } \\
\text { in constant } 2005 \text { US\$ at PPP }\end{array}$ & $\begin{array}{c}\text { World Development Indicators, } \\
2014 \\
\text { The world Bank }\end{array}$ \\
\hline Inflation & Consumer prices index (annual \%) & $\begin{array}{c}\text { World Development Indicators, } \\
2014 \\
\text { The world Bank }\end{array}$ \\
\hline School enrollment & $\begin{array}{l}\text { Percentage of the gross enrolment in } \\
\text { primary school. }\end{array}$ & $\begin{array}{c}\text { World Development Indicators, } \\
2014 \\
\text { The world Bank } \\
\& \\
\text { Bangladesh Bureau of Statistics }\end{array}$ \\
\hline $\begin{array}{l}\text { Government } \\
\text { consumption }\end{array}$ & $\begin{array}{l}\text { Government consumption at the percentage } \\
\text { of GDP }\end{array}$ & $\begin{array}{c}\text { World Development Indicators, } \\
2014 \\
\text { The world Bank }\end{array}$ \\
\hline Numbers of Bank & $\begin{array}{l}\text { Number of brank branches per } 1,000 \text { square } \\
\text { kilometre in Bangladesh }\end{array}$ & $\begin{array}{c}\text { Bangladesh Bank (The central bank } \\
\text { of Bangladesh) }\end{array}$ \\
\hline Trade openness & $\begin{array}{l}\text { Total export-import value at the percentage } \\
\text { of GDP }\end{array}$ & Penn World Table 7.1 \\
\hline
\end{tabular}

